\title{
Comparison of the $S$ genes and the biological properties of respiratory and enteropathogenic bovine coronaviruses
}

\author{
Brief Report \\ X. Zhang ${ }^{1}$, W. Herbst ${ }^{2}$, K. G. Kousoulas ${ }^{1}$, and J. Storz ${ }^{1}$ \\ ${ }^{1}$ Department of Veterinary Microbiology and Parasitology, School of Veterinary Medicine, \\ Louisiana State University, Baton Rouge, Louisiana U.S.A. \\ ${ }^{2}$ Institut für Hygiene und Infektionskrankheiten der Tiere, Justus-Liebig Universität \\ Giessen, Giessen, Federal Republic of Germany
}

Accepted September 7, 1993

Summary. The nucleotide sequence of the $\mathrm{S}$ gene of the bovine respiratory coronavirus (BRCV) strain G95, which was isolated from nasal swabs of a calf suffering from respiratory disorders, was determined and compared with the $S$ gene of the enteropathogenic bovine coronavirus (BECV) strain LY138. Sequence analysis revealed $98.7 \%$ nucleotide and $98.3 \%$ deduced amino acid identities between the S genes of BRCV-G95 and BECV-LY138 without any deletions or insertions. Nucleotide substitutions were distributed randomly throughout the gene. Five monoclonal antibodies specific for the $\mathrm{S}$ protein distinguished BRCV-G95 from BECV-L9, but failed to differentiate it from BECV-LY138 in Western blots under denatured and native conditions. BRCVG95 induced cytopathic changes in cell cultures that were similar to BECVLY138 but different from BECV-L9. These results suggest that strain BRCVG95 is more closely related to the virulent strain BECV-LY138 than to the avirulent, cell culture-adapted strain BECV-L9.

Bovine coronavirus (BCV) causes severe enteritis of newborn calves $[3,11,12]$, and it is also recognized as an etiological factor of respiratory disease of calves $[5,6,9,13,15]$. Comparative studies revealed that coronavirus isolates from the intestinal or respiratory tracts of calves both replicated in intestinal and upper respiratory cells of gnotobiotic calves $[17,18]$. Serological tests failed to distinguish between bovine respiratory coronavirus (BRCV) and enteropathogenic bovine coronavirus (BECV). A porcine respiratory coronavirus (PRCV) had a deletion in the $\mathrm{S}$ gene when compared with the transmissible 
gastroenteritis virus. This deletion was considered most likely responsible for the differences in tissue tropism and pathogenicity of the two viral strains $[2,16]$.

BCV possesses a single-stranded, nonsegmented RNA genome of positive polarity [22]. The virion contains four major structural proteins: the nucleocapsid protein $(\mathrm{N})$, the transmembrane protein $(\mathrm{M})$, the hemagglutinin esterase protein (HE) and the spike protein $(\mathrm{S})[1]$. The $\mathrm{S}$ glycoprotein is the predominant peplomere responsible for the characteristic coronavirus morphology. It is synthesized as a high molecular weight precursor $(190 \mathrm{kDa})$ which is cleaved to yield two comigrating subunit polypeptides: the N-terminal half (S1) and the C-terminal half (S2) with approximate molecular weights of $100-110 \mathrm{kDa}$ $[23,24]$. The $\mathrm{S}$ glycoprotein functions in virus attachment to permissive cells, virus-induced cell fusion, and elicitation of neutralizing antibodies [22].

The BRCV strain Giessen 89-4595-(BRCV-G95) was originally isolated in human rectal tumor (HRT-18) cells [25] from nasal swabs of a calf affected with respiratory disease, and tentatively identified as a $\mathrm{BCV}$ by immunoelectron microscopy and inhibition of hemagglutination with $\mathrm{BCV}$-specific antisera. We report here the comparative analysis of biological and antigenic properties as well as the $\mathrm{S}$ gene sequences of the BRCV-G95 and of BECV.

Viral RNA was isolated from BRCV-infected HRT-18 cells using isothiocyanate/cesium chloride gradients $[10,26]$. cDNA synthesis, PCR amplification and single-stranded cDNA synthesis were performed as reported $[19,26]$. Nucleotide sequences of the complete $S$ gene of the BRCV-G95 were determined from PCR-products in both directions, and were analyzed as described in the legend of Fig. 1.

An open reading frame (ORF) of 4092 nucleotides encoding a protein of 1363 amino acids was identified for BRCV-G95. This ORF has the same size as the $S$ gene of BECV-LY138 [26]. Differences between the S gene sequences of

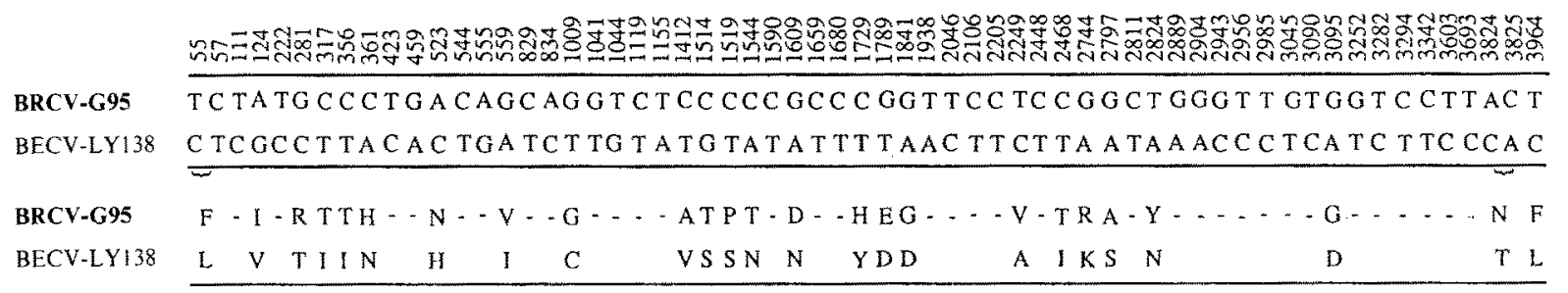

Fig. 1. Comparison of nucleotides and deduced amino acids of the $S$ genes between BRCV-G95 and BECV-LY138. DNA sequencing was carried out with the modified dideoxynucleotide chain termination procedure [19] using Sequenase (USB, Cleveland, OH, U.S.A). Sequence data were analyzed with the aid of the Sequence Analysis Software Package of the Genetics Computer Group of the University of Wisconsin and the MacVector Software (IBI, New Haven, CT, U.S.A). The numbers at the top represent the position of the nucleotide changes in reference to the $S$ gene sequence of BECV-LY138 [23]. The nucleotide sequences of the S gene of BRCV-G95 identical to the S gene of BECV-LY138 are not shown and the complete sequence is deposited in the GenBank/EMBL under accession number M80844. The changes of deduced amino acids are indicated below the nucleotides for the strains listed on the left 
BRCV-G95 and BECV-LY138 consisted of randomly distributed point mutations without any deletions or insertions. The nucleotides and deduced amino acids of the S genes of BRCV-G95, which differ from those of BECV-LY138, are presented in Fig. 1. Sixty-one nucleotides differed between the $S$ genes of BRCV-G95 and BECV-LY138, and 34 of these did not result in any amino acid changes, whereas 27 nucleotide changes coded for 25 different amino acids. The degree of nucleotide and amino acid identity was 98.7 and $98.3 \%$, respectively. The predicted S protein of BRCV-G95 had one N-linked glycosylation site and one cysteine residue less than the $\mathrm{S}$ of BECV-LY138. The putative fusogenic domain and proteolytic cleavage site of the $S$ protein were conserved.

The antigenicity of BRCV-G95 and BECV was compared in Western blots under denatured and native conditions using a panel of monoclonal antibodies (MAbs) specific for the S protein (\#34B8, \#43C2, \#43F6, \#44, \#38, \#31) and the $\mathrm{N}$ protein (\#36, \#46). The characteristics of these MAbs and the procedures for Western blots were described [8]. As shown in Table 1, MAbs \#34B8, 43C2 and 43F6 reacted with gp100 of BRCV-G95, BECV-LY138 and BECV-L9, while MAbs \#44, 38 and 31 reacted with gp 100 of BECV-L9 but not BECV-LY138 and BRCV-G95 in native Western blots. These MAbs did not react with $S$ of the three viruses under denatured Western conditions, except that MAb 34B8 reacted weakly with BRCV-G95. Two N-specific MAbs reacted with $\mathrm{N}$ of all three viruses under denatured and native conditions.

Biological properties such as cytopathic changes with cell fusion, hemagglutination, and acetylesterase activities of BRCV- G95 were compared with those of BECV-LY138 and BECV-L9 (Table 2). All three viral strains agglutinated chicken and mouse erythrocytes. BRCV-G95 and BECV-LY138 agglutinated mouse erythrocytes at 32 -fold higher titers than chicken erythrocytes, while BECV-L9 had only a 4-fold higher titer. Viral acetylesterase activity was determined by the amount of acetate released from bovine submaxillary mucin

Table 1. Antigenic reactivities of BRCV-G95 and BECV with monoclonal antibodies in Western blots

\begin{tabular}{lllllllll}
\hline $\begin{array}{l}\text { Monoclonal } \\
\text { antibodies }\end{array}$ & & \multicolumn{3}{l}{ Denatured western } & & \multicolumn{2}{l}{ Native western } \\
\cline { 3 - 5 } \cline { 6 - 8 } & & BRCV & LY-138 & L9 & BRCV & LY-138 & L9 \\
\hline Anti-S & $34 \mathrm{~B} 8$ & + & - & - & + & + & + \\
& $43 \mathrm{C} 2$ & - & - & - & + & + & + \\
& $443 \mathrm{~F} 6$ & - & - & - & - & + & + & + \\
& 44 & - & - & - & - & - & + \\
& 38 & - & - & - & - & - & + \\
& 31 & - & - & - & - & - & + \\
\hline \multirow{2}{*}{ Anti-N } & 36 & + & + & + & + & + & + \\
& 46 & + & + & + & + & + & + \\
\hline
\end{tabular}


Table 2. Comparison of biological properties between BRCV-G95 and BECV

\begin{tabular}{|c|c|c|c|c|c|c|c|}
\hline \multirow[t]{2}{*}{ Virus } & \multicolumn{4}{|c|}{ Cytopathic effect } & \multicolumn{2}{|c|}{ Hemagglutination titer ${ }^{\mathrm{a}}$} & \multirow{2}{*}{$\begin{array}{l}\text { Acetylesterase } \\
\text { activity } \\
\left(\mu \mathrm{g} \text { acetate }\left\langle\mu \mathrm{l}^{\mathrm{b}}\right)\right.\end{array}$} \\
\hline & HRT-18 & GBK & D2BFS & MDBK & Chicken-RBC & Mouse-RBC & \\
\hline BRCV-G95 & ++ & - & - & - & 64 & 1024 & 2.02 \\
\hline BECV-LY 138 & ++ & - & - & - & 256 & 8192 & 2.86 \\
\hline BECV-L9 & $+t+$ & ++ & ++ & ++ & 1024 & 4096 & 2.15 \\
\hline
\end{tabular}

HRT-18 Human rectal tumor; GBK Georgia bovine kidney; D2BFS bovine fetal spleen, clone D2; $M D B K$ Madin-Darby bovine kidney

${ }^{a}$ Reciprocal value of highest dilution with complete hemagglutination (HA) by $50 \mu$ l of virus preparation in the presence of chicken or mouse red blood cells $(R B C)$

${ }^{b}$ The acetylesterase activity was determined by releasing acetate from substrate bovine submaxillary mucin (BSM) and expressed as $\mu \mathrm{g}$ acetate per $\mu \mathrm{l}$ purified virus preparation as described previously $[7,27]$

according to the method described [7]. Acetylesterase activities of these strains were similar, and ranged from 2.02 to $2.86 \mu \mathrm{g}$ acetate per microliter of purified virus preparation.

BECV-L9 induced cytopathic changes and cell fusion in HRT-18, bovine fetal spleen (D2BFS), Georgia bovine kidney (GBK) and Madin Darby bovine kidney (MDBK) cells while BRCV-G95 and BECV-LY138 induced these changes only in HRT-18 cells (Table 2). The ability of BRCV to replicate in HRT-18 cells which possess the properties of intestinal epithelial cells, indicates this virus may be able to infect both respiratory and intestinal sites of calves. Coronaviruses were frequently isolated from the respiratory as well as intestinal samples of calves with pneumoenteritis when HRT-18 cells were employed (Herbst et al., unpubl. res.) indicating that HRT-18 cell cultures should be included in routine diagnostic viral isolation attempts from respiratory disease of cattle. Comparatively, the porcine respiratory coronavirus replicated in the intestine but at lower titers and without causing enteritis $[2,14]$.

The envelope proteins of coronaviruses play a major role in interactions with cellular receptors and in infection. A small deletion in the amino terminal of the $\mathrm{S}$ protein of the mouse hepatitis virus and PRCV altered their cell tropism and pathogenicity reflecting the function of the $S$ protein in tissue-tropism $[4,16]$. Sequence analysis of the BRCV-G95 did not reveal any deletions or insertions in the $\mathrm{S}$ gene when compared with BECV strains (Fig. 1). Sixty-one single nucleotide changes occurred in the $\mathrm{S}$ genes between BRCV-G95 and BECV. These mutations were found throughout the genes in a random fashion and caused 25 amino acid changes. It is not clear at this point whether these single mutations in the peplomeric proteins contribute to a difference in the pathogenicity of BRCV-G95 and BECV-LY138. Interestingly, the S and the HE glycoproteins of $\mathrm{BCV}$ recognized sialic acid-containing receptors $[20,21]$. The location of the receptor-binding domains on the S protein of $\mathrm{BCV}$ is not known. Whether the single amino acid changes occurring in the $S$ and HE proteins are located within domains involved in virus recognition of cellular receptor determinants remains to be elucidated. The results suggest that the respiratory 
isolate of bovine coronavirus BRCV-G95 should be considered as a member of the hemagglutinating $\mathrm{BCV}$ group rather than as a separate $\mathrm{BRCV}$ group.

\section{Acknowledgements}

This work was supported by Grant 86-CRSR-2-2871 and 89-34116-4675 from the United States Department of Agriculture, and Louisiana Education Quality Support Fund of the Board of Regents, State of Louisiana, to J.S. and K.G.K. K.G.K. was also supported by Grant AI87886 from the National Institute of Health. X.M.Z is a postdoctoral fellow. We thank M. Burrell and L.J.T. Huang for excellent technical assistance. This is Publication No. 109 of the VMP Department "Gene Probe and Expression Systems Laboratory".

\section{References}

1. Cavanagh D, Brian DA, Enjuanes L, Holmes KV, Lai MM, Laude H, Siddell SG, Spaan W, Taguchi F, Talbot PJ (1990) Recommendations of the Corona-virus Study Group for the nomenclature of the structural proteins, mRNAs, and genes of coronaviruses, Virology 176: 306-307

2. Cox E, Pensaert MB, Callebaut P, van Deun DK (1990) Intestinal replication of a porcine respiratory coronavirus closely related antigenically to the enteric transmissible gastroenteritis virus. Vet Microbiol 23: 237--243

3. Doughri AM, Storz J (1977) Light and ultrastructural pathologic changes in intestinal coronavirus infection of newborn calves. Zentralbl Vet Med 24: 367-385

4. Gallagher TM, Parker SE, Buchmeier MJ (1990) Neutralization-resistant variants of a neurotropic coronavirus are generated by deletions within the amino-terminal half of the spike glycoprotein. J Virol 64: 731-741

5. Heckert RA, Saif LJ, Hoblet KH, Agnes AG (1990) A longitudinal study of bovine coronavirus enteric and respiratory infections in dairy calves in two herds in Ohio. Vet Microbiol 22: 187-201

6. Herbst W, Klatt E, Schliesser T (1989) Serologisch- diagnostische Untersuchungen zum Vorkommen von Coronavirusinfektionen bei Atemwegserkrankungen des Rindes. Berl Münch Tierärztl Wochenscht 102: 129-131

7. Herrler G, Rott R, Klenk HD (1985) Neuraminic acid is involved in the binding of influenza $C$ virus to erythrocytes. Virology 141: 144-147

8. Hussain K, Storz J, Kousoulas KG (1991) Comparison of bovine coronavirus (BCV) antigens: Monoclonal antibodies to glycoprotein gp 100 distinguish between vaccine and wild-type strains. Virology 183: 442-445

9. Jimenez C, Herbst W, Biermann U, Müller JM, Schliesser T (1989) Isolierung von Coronaviren in der Zellkultur aus Nasentupferproben atemwegskranker Kälber in der Bundesrepublik Deutschland. J Vet Med B 36: 635-638

10. Kingston, RE (1989) Guanidinium method for total RNA preparation. In: Ausubel FM (ed) Current protocols in molecular biology. Greene Wiley-Interscience, New York, pp 421-425

11. Mebus CA, Stair EL, Rhodes MB, Twiehaus MJ (1973) Pathology of neonatal calf diarrhea induced by a coronavirus-like agent. Vet Pathol 10: 45-64

12. Mebus CA, Stair EL, Rhodes MB, Twiehaus MJ (1973) Neonatal calf diarrhea: propagation, attenuation and characteristics of coronavirus-like agents. Am $J$ Vet Res 34: $145-150$

13. Möstl K, Bürki F (1988) Ursächliche Beteiligung boviner Coronaviren an respiratorischen Krankheitsausbrüchen bei Kälbern und pathogenetisch-immunologische Überlegungen hierzu. Dtsch Tierärztl Wochenschr 95: 19-22 
14. Pensaert $M$, Callebaut $P$, Vergote $J$ (1986) Isolation of a porcine respiratory, non-enteric coronavirus related to transmissible gastroenteritis. Vet Q 8: 257-261

15. Rai RB, Singh NP (1983) Isolation of coronavirus from neonatal calves with pneumoenteritis in India. Vet Rec 113: 47-48

16. Rasschaert D, Duarte M, Laude H (1990) Porcine respiratory coronavirus differs from transmissible gastroenteritis virus by a few genomic deletions. J Gen Virol 71:2599-2607

17. Reynolds DJ, Debney TG, Hall GA, Thomas LH (1985) Studies on the relationship between coronaviruses from the intestinal and respiratory tracts of calves. Arch Virol $85: 71-83$

18. Saif LJ, Redman DR, Moorhead PD, Theil KW (1986) Experimentally induced coronavirus infections in calves: viral replication in the respiratory and intestinal tracts. Am J Vet Res 47: 1426-1432

19. Sanger F, Nicklen S, Coulson AR (1977) DNA sequencing with chain-terminating inhibitors. Proc Natl Acad Sci USA 74: 5463-5467

20. Schultze B, Wahn K, Klenk HD, Herrler G (1991) Isolated HE-protein from hemagglutinating encephalomyelitis virus and bovine coronavirus has receptordestroying and receptor-binding activity. Virology 180: 221-228

21. Schultze B, Gross HJ, Brossmer R, Herrler G (1991) The S protein of bovine coronavirus is a hemagglutinin recognizing 9-0- acetylated sialic acid as a receptor determinant. $\mathrm{J}$ Virol 65: 6232-6237

22. Spaan W, Cavanagh D, Horzinek MC (1988) Coronaviruses: structure and genome expression. J Gen Virol 69: 2939-2952

23. St Cyr-Coats K, Storz J (1988) Bovine coronavirus induced cytopathic expression and plaque formation: host cell and virus strain determine trypsin dependence. $J$ Vet Med B 35: $48-56$

24. Sturman LS, Ricard CS, Holmes KV (1985) Proteolytic cleavage of the E2 glycoprotein of murine coronavirus: activation of cell-fusing activity of virions by trypsin and separation of two different $90 \mathrm{~K}$ cleavage fragments. J Virol 56: 904-911

25. Tompkins WAF, Watrach AM, Schmale JD, Schultz RM, Harris JA (1974) Cultural and antigenic properties of newly established cell strains derived from adenocarcinomas of the human colon and rectum. J Natl Cancer Inst 52: 904-911

26. Zhang XM, Kousoulas KG, Storz J (1991) Comparison of the nucleotide and deduced amino acid sequences of the $S$ genes specified by virulent and avirulent strains of bovine coronaviruses. Virology 183: 397-404

27. Zhang XM, Kousoulas KG, Storz J (1991) The hemagglutinin/esterase glycoprotein of bovine coronaviruses: sequence and functional comparisons between virulent and avirulent strains. Virology 185: 847-852

28. Zhang XM, Kousoulas KG, Storz J (1992) The hemagglutinin/esterase gene of human coronavirus strain OC43: phylogenetic relationships to bovine and murine coronaviruses and influenza $\mathrm{C}$ virus. Virology 186: 318-323

Authors' address: Dr. J. Storz, Department of Vaterinary Microbiology and Parasitology, Louisiana State University, Baton Rouge, LA 70803, U.S.A.

Received June 23, 1993 